\title{
BEHAVIOR OF SOME GRAPEVINE CULTIVARS FROM MURFATLAR VINEYARD IN THE SPECIAL CLIMATIC CONDITIONS OF THE WINE YEAR 2019-2020
}

\author{
I. Dina1* ${ }^{*}$ A. Ranca1 ${ }^{1}$ A. Tănase ${ }^{1}$ and S.A. Ene ${ }^{1}$ \\ 1Research and Development Station for Viticulture and Oenology Murfatlar, Calea \\ București, nr. 2, 905100, Murfatlar, Constanța, Romania \\ * Corresponding author, email: dinaionica@yahoo.com
}

\begin{abstract}
The climate changes in Murfatlar vineyard in recent years consist inthe increase ofmonthly average temperatures, recorded in both cold and warm seasons, accompanied by an irregular distribution of rainfall during the year, which significantly influences the growth of grapevine, the quality and production of grapes.Six representative cultivars were studied, three for white wines: Chardonnay, Columna and Muscat Ottonel and three for red wines: Fetească Neagră, Mamaia and Cabernet Sauvignon. In the last two years (2019-2020) warm winters and very dry summers have led to the onset of budburst, almost simultaneously for all the studied cultivars, followed by a very weak growth and development of shoots (2020) and an acceleration development of phenophases, mainly berween veraison and ripening. Water stress during the vegetative period, a hygroscopicity below $60 \%$ between July and August and low vegetative apparatus influenced the growth ofthe berries, resulting small grapes, and a very low must yield in 2020 .Concerning the quality of grape production, the studied cultivars achieved more sugar concentrations in berries up to $35.8 \mathrm{~g} / \mathrm{L}$ (in 2019) and $36.0 \mathrm{~g} / \mathrm{L}$ (in 2020), higher than the values obtained in normal years. In the conditions of a pronounced dry climate manifested in the two years of study, the productions were below the normal level, especialy in 2020, achieving much diminished productions for all cultivars, except the Mamaia cultivar. The Mamaia cultivar had a positive reaction, registering an increase of production, that exceeded the multiannual value by $20 \%$ in 2020 andby $10 \%$ in 2019, the concentration of sugars in the must being above the average value obtained in normal years, exceeding by $3 \%$ and $9 \%$, respectively, the multiannual average. Statistical calculations were done using SPSS Statistics 17.0, using mainly the Duncan test for a degree of significance of $5 \%$.
\end{abstract}

Keywords: climate change, phenology, cultivar adaptability, productivity and quality

\section{INTRODUCTION}

Climate changes in recent times had led to an increase in the average annual temperature, based mainly on average monthly values in winter and summer, a decrease in rainfall, much lower in summer, and an increase in the frequency of very drought years.

All these changes lead to a rapid development of vegetative phenophases (Cichi, 2006; Dejeu et al., 2008) leading to a shortening of the period of development and maturation of grapes and a low productivity in vineyards. 
The choice of vine cultivars with increased adaptability to abiotic stress along with the improvement of cultivation technology is the most efficient way to ensure a constant and quality wine production.

\section{MATERIALS AND METHODS}

To describe the reaction of vine cultivars to climatic factors specific to the wine year and to the local area, between November 1, 2018 and October 30, 2020, observations were made on the succession of vegetative phenophases (noting the date when $50 \%$ of plants have physiologically reached that stage), using 3 grape cultivars for white wines and 3 for red wines, representative for the Murfatlar viticultural center: Columna, Muscat Ottonel, Chardonnay, respectively Mamaia, Fetească Neagră and Cabernet Sauvignon.

Research on the behavior of these cultivars was carried out in the plantations of the Research and Development Station for Viticulture and Oenology Murfatlar.

The studied cultivars were grafted on the same rootstock, the Oppenheim Selection 4 clone 4 and training system form adopted was the classic Guyot, with a fruit load of 34-38 buds per stem and a planting distance of $2.2 / 1.1 \mathrm{~m}$. The plots cultivated with the Columna, Mamaia, and Cabernet Sauvignon cultivars are located on a land with E-W exposure and the plots cultivated with Chardonnay, Muscat Ottonel and Feteasca neagră have an N-S exposure, with slope of $2-3 \%$ and a calcareous chernozem soil with a clayey texture and a granular-porous glomerular structure with a humus content of $2.3 \%$.

For monitoring the climatic elements, we utilised our own meteorological station (iMetos 3.3) located in the center of the vine plantation. Daily observations were made concerning the maximum and minimum temperatures, sunshine, relative air humidity and precipitation based on which the evolution of abiotic stress in the two wine years (November 2018 October 2020) was determined compared to the multiannual average (1989-2018).

In order to characterize the heliothermal and hydric resources during this interval, a series of synthetic ecological indicators were used: the real heliothermal index (Branas et al., 1946); the hydrothermal coefficient (Seleaninov, 1936); the bioclimatic index of the vine (Constantinescu et al., 1936) and the oenoclimatic aptitude index (Teodorescu, 1987), the heliothermal index (IH) (Huglin,1978)and the cool night index (IF) (Tonietto et al., 2000). In order to determine the drought affect on the vegetative growths, at the beginning of veraison, when the intense growth of the shoots ceased, the minimum, maximum and average length of the shoots was determined.The grape production was determined at harvest, establishing the average production per hectare.For the determination of the sugar content $(\mathrm{g} / \mathrm{L})$ the refractrometric method was used (Babeș, 2011) and for the total acidity $\left(\mathrm{g} / \mathrm{L} \mathrm{H}_{2} \mathrm{SO}_{4}\right.$ ) the titrimetric method.

\section{RESULTS AND DISCUSSIONS}

During the rest period, the average monthly temperatures recorded registere an average thermal increased than average with $2.7^{\circ}$ to 4.1 C.In the first part of the period of active vegetation, that includes the phenophases budburst and shoot growth, the average monthly temperature increased by $2.0-2.4^{\circ} \mathrm{C}$ in the both studied years. The average temperatures in July, August and September have higher values by up to $6.6^{\circ} \mathrm{C}$ (June 2019) being favorable for obtaining quality grape productions. (Figure 1).

The amount of precipitation recorded in the wine year 2018-2019 represent $60 \%$ of the multiannual average $(311.4 \mathrm{~mm})$ and in the wine year $2019-2020$ represent $66 \%$ of the multiannual average $(340.5 \mathrm{~mm})$. During the vegetative period, the amount of precipitation was $139.6 \mathrm{~mm}$ in the wine year 2018-2019 (106.1 mm less than the 
multiannual average) and $161.7 \mathrm{~mm}$ in the wine year 2019-2020 (84 $\mathrm{mm}$ below the multiannual average) (Figure 2).

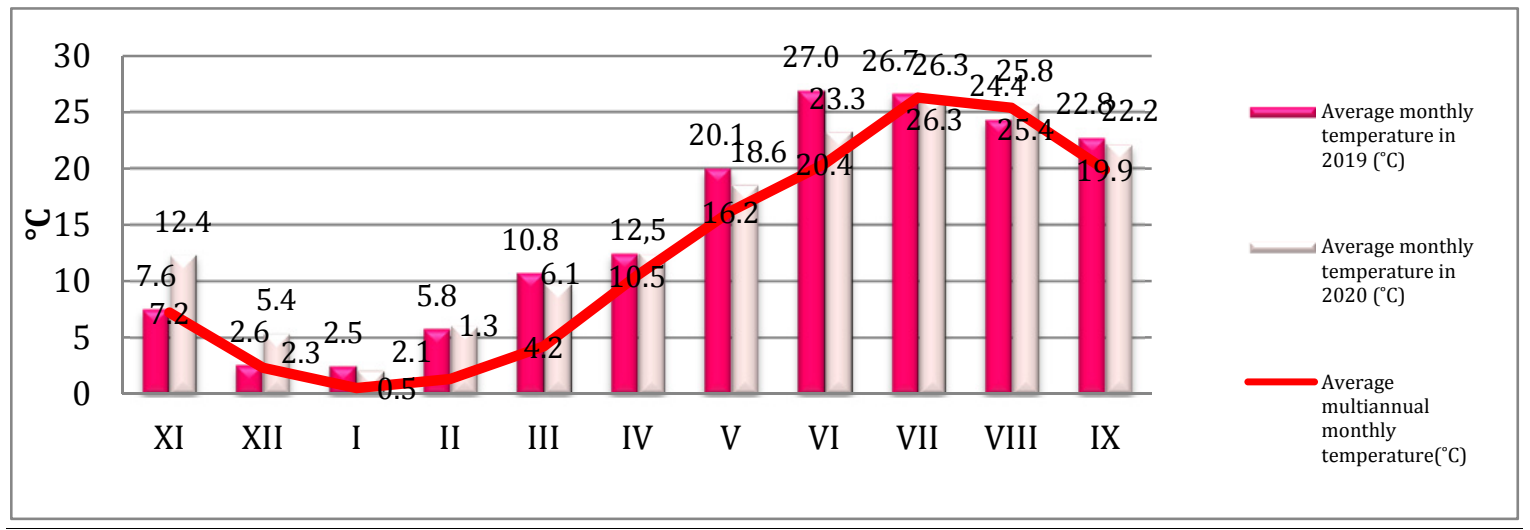

Figure 1. The evolution of the average monthly temperature period of grapvine, Murfatlar, 20192020

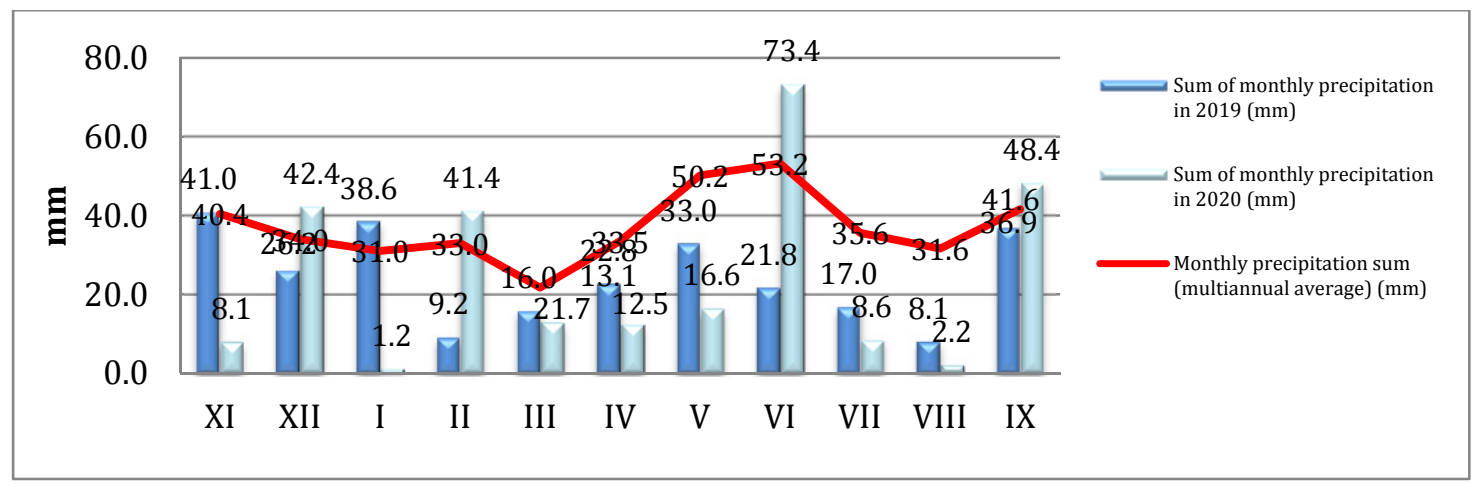

Figure 2. The sum of precipitation recorded, Murfatlar, 2019-2020

In 2018-2019 the relative humidity of the air during the vegetation period had normal values, however, in the wine year 2019-2020, in April, during the budburst phenophase, the atmospheric hygroscopicity was below $60 \%$ and during the berry growth and maturation it had values of 51-53\%. (Figure 3).

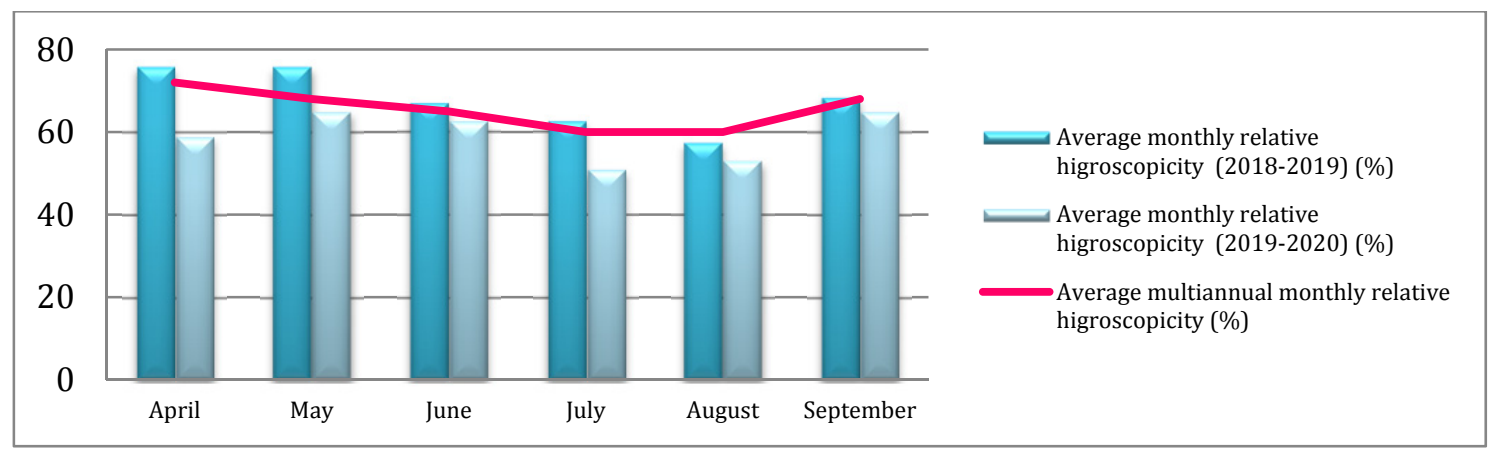

Figure 3. Montly relative air higroscopicity registered during the vegetative period of grapevine, Murfatlar, 2019-2020 
The interval between November 2018 and October 2020 was characterized by the following ecoclimatic elements: the average annual temperature compared to the multiannual average (1989-2018) was $1.3^{\circ} \mathrm{C}$ higher in 2019 and $1.6^{\circ} \mathrm{C}$ in 2020 . The global and active thermal balance had values with $520-565^{\circ} \mathrm{C}$ higher than the multiannual average and the useful thermal balance in the wine year $2018-2019$ was $2811,8^{\circ} \mathrm{C}$, and $2477,3^{\circ} \mathrm{C}$ in the wine year $2019-2020$, being with $506^{\circ} \mathrm{C}$, respectively $173,5^{\circ} \mathrm{C}$, more than the multiannual average value(Table 1 ).

The real heliothermal index (IHr) in Romania varies between 1.35 and 2.70. The average value of this index was 3.9. In the period 2019-2020 this index had increased values in the range of $4.0-4.5$, which indicates rich heliothermal resources.

The hydrothermal coefficient $(\mathrm{CH})$, in the Murfatlar viticultural centre has an average multiannual value of 0.8 and in the studied interval it had values of 0.4 indicating the need of irrigations.

The bioclimatic index of the vine (Ibcv), presents on the Romanian territory a pronounced variation, from the value 4.0 (in the vineyards of the north of the country), to 15.0 in the south.The value determined for this interval was 22 and 18, indicating years rich in heliothermal resources but very deficient in precipitation.

The oenoclimatic aptitude index (IAOe) presents a certain zonality in Romanian viticulture, having increasing values from the cooler climate (3700) to the warm climate (5200). In the Murfatlar vineyard this index has a multiannual average value of 5331.7 and in the studied years it was close to the multiannual average(5538.7 in 2019-2020 and 5847.7 in 2018-2019) that indicate favorable conditions for obtaining quality red wines.

The Huglin heliothermal index ( $\mathrm{IH}$ ) indicates the optimal conditions for obtaining quality grapes. In the wine year 2018-2019 the value of this index was 4583.7, higher than the multiannual value (3243.4) and registered a value very close to it in 2019-2020 (3138.8).

The cool night index has average value of 14.2 and in the years studied it had values of 14.4 - 14.5, indicating a climate with temperate nights.

Table 1. Values of the climate factors recorded between November 2018 and October 2020 at Murfatlar

\begin{tabular}{|c|c|c|c|}
\hline \multirow{2}{*}{ Analyzed climatic elements } & \multirow{2}{*}{$\begin{array}{c}\text { Average } \\
\text { nov.1989- oct.2018 }\end{array}$} & \multicolumn{2}{|c|}{ Viticultural year } \\
\cline { 3 - 4 } & 4982.4 & 5534.4 & 5515.4 \\
\hline Global thermal sum, $\left(\sum \mathrm{t}^{\circ} \mathrm{g}\right)$ & 4496.3 & 5061.8 & 5016.4 \\
\hline Active thermal sum, $\left(\sum \mathrm{t}^{\circ} \mathrm{a}\right)$ & 2303.8 & 2811.8 & 2477.3 \\
\hline Useful thermal sum, $\left(\sum \mathrm{t}^{\circ} \mathrm{u}\right)$ & 26.3 & 26.7 & 26.3 \\
\hline Average temperature in July, ${ }^{\circ} \mathrm{C}$ & 25.4 & 27.5 & 25.8 \\
\hline Average temperature in August, ${ }^{\circ} \mathrm{C}$ & 19.9 & 22.8 & 21.7 \\
\hline Average temperature in September, ${ }^{\circ} \mathrm{C}$ & -14.5 & -10.5 & -13.9 \\
\hline Absolute minimum air temperature, ${ }^{\circ} \mathrm{C}$ & -15.6 & -15.0 & -13.7 \\
\hline $\begin{array}{c}\text { Absolute minimum temperature at soil } \\
\text { surface, },{ }^{\circ} \mathrm{C}\end{array}$ & 13.5 & 14.8 & 15.1 \\
\hline Average annual temperature ${ }^{\circ} \mathrm{C}$ & 3.1 & 5.8 & 7.2 \\
\hline $\begin{array}{c}\text { Average monthly temperature in the } \\
\text { rest months }{ }^{\circ} \mathrm{C}\end{array}$ & 37.3 & 39.0 & 39.0 \\
\hline Maximum air temperature, ${ }^{\circ} \mathrm{C}$ & & & \\
\hline
\end{tabular}




\begin{tabular}{|c|c|c|c|}
\hline Sum of annual precipitation, $\mathrm{mm}$ & 514.5 & 311.4 & 340.5 \\
\hline $\begin{array}{c}\text { Sum of precipitation during the rest } \\
\text { period, } \mathrm{mm}\end{array}$ & 160.1 & 131.0 & 106.2 \\
\hline $\begin{array}{l}\text { Sum of precipitation during the } \\
\text { vegetation period, mm }\end{array}$ & 317.4 & 180.4 & 161.7 \\
\hline $\begin{array}{l}\text { Sum of insolation hours during the } \\
\text { vegetation period, hours }\end{array}$ & 1667.8 & 2125.5 & 1574.7 \\
\hline $\begin{array}{c}\text { Average maximum temperatures in } \\
\text { August, }{ }^{\circ} \mathrm{C}\end{array}$ & 31.2 & 33.8 & 30.4 \\
\hline $\begin{array}{l}\text { Average temperatures in the I and II } \\
\text { decades of July }\end{array}$ & 23.4 & 26.3 & 22.1 \\
\hline $\begin{array}{l}\text { Number of days with maximum } \\
\text { temperatures }>30^{\circ} \mathrm{C}\end{array}$ & 56 & 98 & 63 \\
\hline Real Heliothermic index (IHr) & 3.9 & 4.5 & 4.0 \\
\hline Hydrothermic coefficient $(\mathrm{CH})$ & 14.4 & 0.4 & 0.5 \\
\hline Bioclimatic index (Ibcv) & 14.2 & 22.6 & 18.0 \\
\hline Enological aptitudie index (IAOe) & 5321.7 & 5847.5 & 5538.7 \\
\hline Huglin heliothermic index (IH) & 3243.4 & 4583.7 & 3138.8 \\
\hline Cool night index (IF) & 14.2 & 14.4 & 14.5 \\
\hline
\end{tabular}

In this climatic context, the vegetative phenophases had a much faster development in 2020 (Table 2).

Table 2. Date of completion of the main vegetative phenophases for the studied cultivars, Murfatlar, 2019-2020

\begin{tabular}{|c|c|c|c|c|c|c|c|}
\hline \multirow{2}{*}{ CULTIVAR } & YEAR & \multicolumn{5}{|c|}{ Phenophases } & $\begin{array}{c}\text { Days from } \\
\text { budburst } \\
\text { until } \\
\text { maturation }\end{array}$ \\
\cline { 3 - 8 } & & Budburst & Flowering & Veraison & $\begin{array}{c}\text { Full } \\
\text { maturity }\end{array}$ & $\begin{array}{c}\text { Harvest } \\
\text { date }\end{array}$ & $\begin{array}{c}\text { Cabernet } \\
\text { Sauvignon }\end{array}$ \\
\cline { 2 - 8 } & 2019 & 30.04 & 08.06 & 17.08 & 23.09 & 30.09 & 147 \\
\hline \multirow{2}{*}{ Chardonnay } & 2019 & 26.04 & 05.06 & 18.08 & 18.09 & 24.09 & 146 \\
\cline { 2 - 8 } & 2020 & 18.04 & 06.06 & 07.08 & 09.09 & 17.09 & 145 \\
\hline \multirow{2}{*}{ Muscat Ottonel } & 2019 & 21.04 & 04.06 & 04.08 & 28.08 & 02.09 & 135 \\
\cline { 2 - 8 } & 2020 & 19.04 & 04.06 & 06.08 & 10.09 & 14.09 & 143 \\
\hline \multirow{2}{*}{ Fetească Neagră } & 2019 & 24.04 & 08.06 & 09.08 & 09.09 & 10.09 & 139 \\
\cline { 2 - 8 } & 2020 & 22.04 & 04.06 & 09.08 & 04.09 & 11.09 & 136 \\
\hline \multirow{2}{*}{ Columna } & 2019 & 23.04 & 09.06 & 14.08 & 12.09 & 17.09 & 143 \\
\cline { 2 - 8 } & 2020 & 21.04 & 04.06 & 12.08 & 10.09 & 16.09 & 143 \\
\hline \multirow{2}{*}{ Mamaia } & 2019 & 26.04 & 04.06 & 09.08 & 15.09 & 16.09 & 143 \\
\cline { 2 - 8 } & 2020 & 21.04 & 04.06 & 11.08 & 10.09 & 18.09 & 143 \\
\hline
\end{tabular}

The studied cultivars had a comparable development of phenophases during the twoo studie years, being observed a shortening of the period between veraison and full maturity, mainly in the 2020 . 
At the beginning of veraison, when the intense growth of the shoots has stoped, the minimum, maximum and average length of the shoots was determined. For these, shoots from 5 trunks of each cultivar were measured and it was observed that in 2020 the shoot growth was 39\% lower than in 2019. The lowest shoot growth was recorded in the Chardonnay cultivar $(38.9 \mathrm{~cm}$ ) (Table 3$)$.

Table 3. Data concerningvine shoot lengths at the beginning of veraison, Murfatlar, 2019, 2020

\begin{tabular}{|c|c|c|c|c|c|c|c|}
\hline \multirow{2}{*}{ No. } & Cultivar & \multicolumn{6}{|c|}{ Shoot length (cm) } \\
\cline { 3 - 8 } & & \multicolumn{3}{|c|}{ Winimum } \\
\cline { 3 - 8 } & $(\mathrm{cm})$ & $\begin{array}{c}\text { Maximum } \\
(\mathrm{cm})\end{array}$ & $\begin{array}{c}\text { Average } \\
\text { shooth } \\
\text { length } \\
(\mathrm{cm})\end{array}$ & $\begin{array}{c}\text { Minimum } \\
(\mathrm{cm})\end{array}$ & $\begin{array}{c}\text { Maximum } \\
(\mathrm{cm})\end{array}$ & $\begin{array}{c}\text { Average } \\
\text { shooth } \\
\text { length } \\
\text { (cm) }\end{array}$ \\
\hline 1 & Chardonnay & 87.2 & 154.1 & 136.2 & 18.0 & 51.4 & 38.9 \\
\hline 2 & Columna & 96.4 & 232.2 & 176.4 & 39.5 & 213.1 & 62.3 \\
\hline 3 & Muscat Ottonel & 41.4 & 1683 & 121.2 & 27.0 & 131.5 & 56.1 \\
\hline 4 & Fetească Neagră & 103.2 & 2371 & 189.4 & 26.5 & 170.2 & 95.3 \\
\hline 5 & Mamaia & 104.5 & 218.6 & 182.4 & 13.0 & 105.5 & 54.7 \\
\hline 6 & $\begin{array}{c}\text { Cabernet } \\
\text { Sauvignon }\end{array}$ & 48.1 & 176.5 & 139.2 & 32.0 & 88.0 & 45.7 \\
\hline
\end{tabular}

The weight of 100 berries $(\mathrm{g})$, together with the sugar content $(\mathrm{g} / \mathrm{L})$ and the total acidity $\left(\mathrm{g} / \mathrm{L} \mathrm{H}_{2} \mathrm{SO}_{4}\right)$ are the main analytical characteristics that offer a complete characterization of the grapes at harvest (Table 4).

Comparing the elements of productivity and quality that characterize the vine cultivars in the studied wine years (under conditions of an excessive water stress during the vegetative period) with the average of 2014-2018, it can be seen that in the wine year 2019 the productions were close to the average multiannual value for Columna $(5074 \mathrm{~kg}$ compared to $5070 \mathrm{~kg}$ ), Cabernet Sauvignon (4884 kg compared to $5160 \mathrm{~kg}$ ), Chardonnay (5096 kg compared to $5606 \mathrm{~kg}$ ).Yields were above the annual average for Muscat Ottonel (5013 kg compared to 3895 multiannual average) and Mamaia (5781 kg compared to 4803 kg multiannual average), and below the multiannual average for the Fetească Neagră cultivar (1694 kg lower than the multiannual average).

In 2020, the water stress induced by the lack of precipitation during both the rest and the vegetative period (which led to an irregular budburst and development of the vegetative apparatus), determined productions per hectare below the average value of 2019. The lowest yields were recorded for Chardonnay and Cabernet Sauvignon cultivars (minus 532 $\mathrm{kg} / \mathrm{ha}$ and minus $1188 \mathrm{~kg} / \mathrm{ha}$ ), which had a vegetative apparatus based on shoots with low growth (average length of shoots reached $38.9 \mathrm{~cm}$ in Chardonnay and $45.7 \mathrm{~cm}$ in Cabernet Sauvignon) develeopedirregular along the cane length. For Columna, Muscat Ottonel and Fetească Neagră cultivars, the production was 50\% below the average of 2014-2018, and for the Mamaia cultivar the average production per hectare was higher than the multiannual average (4803 kg/ha).The average weight of 100 berries for all cultivars was below the multiannual average in 2020, but in 2019 only for the Columna and Muscat Ottonel cultivars was lower and higher for the other cultivars. 
Table 4. Data concerning the productivity and quality of the harvest for the studied cultivars, Murfatlar, 2019-2020

\begin{tabular}{|c|c|c|c|c|c|c|}
\hline \multirow{3}{*}{ Cultivar } & \multirow{3}{*}{ Year } & \multirow{2}{*}{\multicolumn{2}{|c|}{ Average yield }} & \multirow{3}{*}{$\begin{array}{l}\text { Weight of } \\
100 \\
\text { berries } \\
(\mathrm{g})\end{array}$} & \multicolumn{2}{|c|}{$\begin{array}{l}\text { Physico-chemical } \\
\text { characteristics of the must }\end{array}$} \\
\hline & & & & & \multirow{2}{*}{$\begin{array}{c}\text { Sugars } \\
\text { (g/L) }\end{array}$} & \multirow{2}{*}{$\begin{array}{c}\text { Total } \\
\text { acidity } \\
\left(\mathrm{g} / \mathrm{LH}_{2} \mathrm{SO}_{4}\right)\end{array}$} \\
\hline & & $\mathrm{kg} / \mathrm{ha}$ & $\mathrm{kg} /$ trunk & & & \\
\hline \multirow[b]{2}{*}{ Chardonnay } & $\begin{array}{c}\text { 2014-2018 } \\
\text { Average }\end{array}$ & $5606 \pm 50(a)$ & $\begin{array}{r}1,356 \pm 0,25 \\
\text { (a) }\end{array}$ & $112 \pm 5(b)$ & $221,9 \pm 5,7$ (b) & $\begin{array}{r}5,21 \pm 0,72 \\
(\mathrm{a}) \\
\end{array}$ \\
\hline & $\begin{array}{c}\text { Wine year } \\
2019 \\
\text { Wine year } \\
2020 \\
\end{array}$ & $5096 \pm 37(b)$ & $1,23 \pm 0,20$ (a) & $141 \pm 7(a)$ & $223,5 \pm 6,2(b)$ & $\begin{array}{r}4,5 \pm 0,48 \\
(\mathrm{ab})\end{array}$ \\
\hline \multirow[b]{2}{*}{ Columna } & $\begin{array}{c}\text { 2014-2018 } \\
\text { Average }\end{array}$ & $532 \pm 10(c)$ & $\begin{array}{r}0,128 \pm 0,03 \\
(b)\end{array}$ & $98 \pm 3$ (c) & $246 \pm 4,5(a)$ & $\begin{array}{r}3,62 \pm 0,31 \\
(\mathrm{~b}) \\
\end{array}$ \\
\hline & $\begin{array}{c}\text { Wine year } \\
2019 \\
\text { Wine year } \\
2020 \\
\end{array}$ & $5070 \pm 45(b)$ & $\begin{array}{r}1,338 \pm 0,33 \\
\text { (a) }\end{array}$ & $192 \pm 8(\mathrm{a})$ & $179,9 \pm 3,7$ (a) & $\begin{array}{r}4,42 \pm 0,52 \\
\text { (a) }\end{array}$ \\
\hline \multirow[b]{2}{*}{$\begin{array}{l}\text { Muscat } \\
\text { Ottonel }\end{array}$} & $\begin{array}{c}\text { 2014-2018 } \\
\text { Average }\end{array}$ & $\begin{array}{r}5174 \pm 270 \\
\text { (a) }\end{array}$ & $\begin{array}{r}1,365 \pm 0,37 \\
(\mathrm{a})\end{array}$ & $186 \pm 7$ (a) & $179,9 \pm 3,1(a)$ & $3,5 \pm 0,47(a)$ \\
\hline & $\begin{array}{c}\text { Wine year } \\
2019 \\
\text { Wine year } \\
2020 \\
\end{array}$ & $\begin{array}{r}2640 \pm 30 \\
\text { (c) }\end{array}$ & $\begin{array}{r}0,696 \pm 0,08 \\
\text { (b) }\end{array}$ & $158 \pm 5$ (b) & $181,1 \pm 2,9$ (a) & $\begin{array}{r}3,75 \pm 0,35 \\
\text { (a) }\end{array}$ \\
\hline \multirow[b]{2}{*}{$\begin{array}{l}\text { Fetească } \\
\text { Neagră }\end{array}$} & $\begin{array}{c}\text { 2014-2018 } \\
\text { Average }\end{array}$ & $3895 \pm 36(b)$ & $\begin{array}{r}0,974 \pm 0,05 \\
(\mathrm{a})\end{array}$ & $169 \pm 4(a)$ & $\begin{array}{r}217,2 \pm 4,5 \\
(\mathrm{a}) \\
\end{array}$ & $\begin{array}{r}4,13 \pm 0,30 \\
(\mathrm{a}) \\
\end{array}$ \\
\hline & $\begin{array}{c}\text { Wine year } \\
2019 \\
\text { Wine year } \\
2020 \\
\end{array}$ & $\begin{array}{r}5013 \pm 49 \\
\text { (a) }\end{array}$ & $\begin{array}{r}1,213 \pm 0,21 \\
(\mathrm{a})\end{array}$ & $150 \pm 3(\mathrm{~b})$ & $\begin{array}{r}219 \pm 3,6 \\
\text { (a) }\end{array}$ & $3 \pm 0,25$ (b) \\
\hline \multirow[b]{2}{*}{ Mamaia } & $\begin{array}{c}\text { 2014-2018 } \\
\text { Average }\end{array}$ & $\begin{array}{r}2836 \pm 30 \\
(c)\end{array}$ & $\begin{array}{r}0,684 \pm 0,03 \\
(b)\end{array}$ & $115 \pm 3$ (c) & $\begin{array}{r}220,2 \pm 4,0 \\
(\mathrm{a}) \\
\end{array}$ & $\begin{array}{r}3,48 \pm 0,37 \\
\text { (b) }\end{array}$ \\
\hline & $\begin{array}{c}\text { Wine year } \\
2019 \\
\text { Wine year } \\
2020\end{array}$ & $\begin{array}{r}6382 \pm 52 \\
\text { (a) }\end{array}$ & $\begin{array}{r}1,679 \pm 0,30 \\
\text { (a) }\end{array}$ & $126 \pm 7$ (b) & $220,6 \pm 5,0(\mathrm{~b})$ & $\begin{array}{r}4,24 \pm 0,20 \\
\text { (a) }\end{array}$ \\
\hline \multirow[b]{2}{*}{$\begin{array}{l}\text { Cabernet } \\
\text { Sauvignon }\end{array}$} & $\begin{array}{c}\text { 2014-2018 } \\
\text { Average }\end{array}$ & $4688 \pm 40(\mathrm{~b})$ & $\begin{array}{r}1,134 \pm 0,15 \\
\text { (b) }\end{array}$ & $142 \pm 9$ (a) & $256,4 \pm 5,8$ (a) & $4,2 \pm 0,27$ (a) \\
\hline & $\begin{array}{c}\text { Wine year } \\
2019 \\
\text { Wine year } \\
2020\end{array}$ & $2200 \pm 31$ (c) & $\begin{array}{r}0,532 \pm 0,03(\mathrm{c} \\
\text { ) }\end{array}$ & $125 \pm 5(b)$ & $256,6 \pm 5,3(a)$ & $\begin{array}{r}3,16 \pm 0,22 \\
\text { (b) }\end{array}$ \\
\hline
\end{tabular}

Mean values \pm standard deviation $(n=3)$. The letters denote the significance $p<0.05$ of the differences among data. Any two values followed by at least one common letter do not differ significantly.

The quality of production in 2020 was superior to the average of 2014-2018 for all the studied cultivars. The highest concentration of sugars was recorded for the cultivars Fetească Neagră (256.6 g/l) and Chardonnay (246.9 g/L).

Compared to the multiannual average, the concentration of sugars $(\mathrm{g} / \mathrm{L})$ accumulated in 2019 was higher for Mamaia (206.6 g/L), Chardonnay (223.5 g/L), Fetească Neagră (highest sugar concentration - $256.4 \mathrm{~g} / \mathrm{L}$ ) and Cabernet Sauvignon $(210.8 \mathrm{~g} / \mathrm{L})$.

The total acidity of grapeshad values between 3.00-5.0 g/L $\mathrm{H}_{2} \mathrm{SO}_{4}$, below the multiannual average, generally low, due to the specificity of the Murfatlar viticultural area.Water stress during the vegetative period, hygroscopicity below $60 \%$ in July and August and a reduced vegetative apparatus directly influenced the growth and development 
of the berries, obtaining a very low must yield in 2020 with values in the range of 50.0 $61.2 \%$ (on average $19.0 \%$ lower than the average of $2014-2018$ and $15 \%$ below the average of 2019). In 2019, the must yield was $66.7-69.8 \%$ (on average $4 \%$ less than the averageof 2014 - 2018) (Figure 9).In 2020, most cultivars had a must yield of 50-51\%, less Columna and Mamaia cultivars, which had a yield of $60.0 \%$ and $61.2 \%$, respectively.

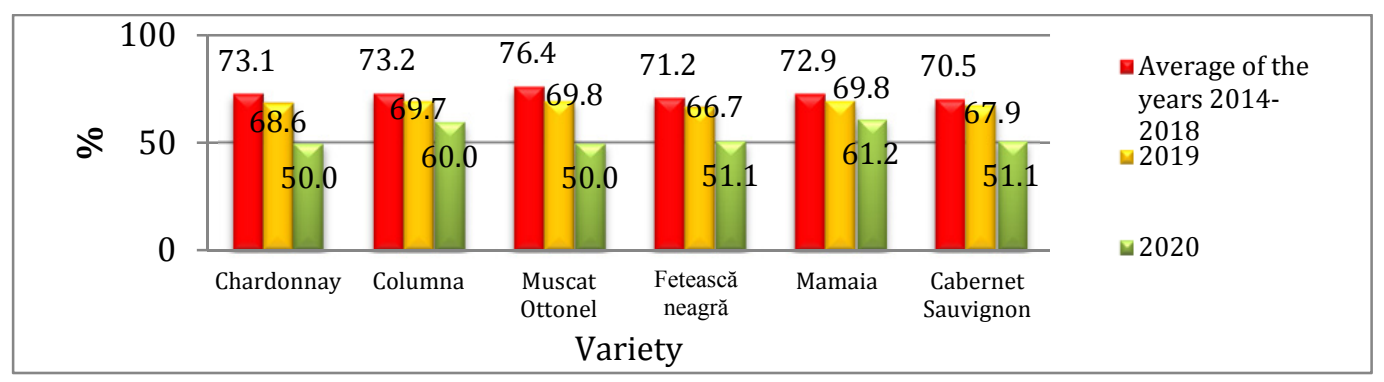

Figure 9. Grapes yield must for the studied cultivars, Murfatlar 2019-2020

\section{CONCLUSIONS}

- The special climatic conditions (drought and high temperatures) manifested during the period of rest and active vegetation of the vine influenced in a strong manner the vegetative phenophases, the growth and development of shoots, productivity and quality of production.

- The cultivars studied in 2020 registered an irregular start in vegetation, influencing the growth and development of the vegetative apparatus, but also the fertility and productivity of the trunks.

- The small amount of precipitation and the relative humidity of the air, with values below $60 \%(51-53 \%)$, directly influenced the growth and development of the berries, obtaining small grapes, not specific to the studied cultivars and a must yield below the average multiannual value, by $4 \%$ in 2019 and $19.0 \%$ in 2020 .

- From the point of view of the quality of grape production, the studied cultivars achieved concentrations in sugars above the average of 2014-2018. The highest sugar concentrations were accumulated in Fetească Neagră and Chardonnay $(256.6 \mathrm{~g} / \mathrm{l}$ and $246.9 \mathrm{~g} / \mathrm{l}$ respectively) in 2020.

- In the conditions of a pronounced dry climate, manifested in the two years of study, only Mamaia cultivar registered a higher production $(5289 \mathrm{~kg} / \mathrm{ha}$ compared to $4803 \mathrm{~kg} / \mathrm{ha}$ average of 2014 -2018), a must yield of 61,2\% (in 2020), 69.8\% (in 2019) and a sugar concentration of $206.6 \mathrm{~g} / \mathrm{L}$ (in 2019), respectively of 204,5 g/L (in 2020) with an acidity of 3,50 and 3,68 g/ $\mathrm{L} \mathrm{H}_{2} \mathrm{SO}_{4}$.

\section{REFERENCES}

1. Babeș A., 2011, Ampelografie, lucrări practice, Editura Academic Pres, Cluj Napoca;

2. Branas J. şi colab., 1946, Elements de viticulture generale, Montpellier;

3. Cichi Daniela, 2006, Modificările termice din ecosistemul viticol (Cauze, efecte asupra viţei de vie, studii). Editura Universitaria, Craiova;

4. Constantinescu Gh. şi colab.,1964, Ampelografia Republicii Socialiste România Vol. I-VII, Editura Academiei, București;

5. Dejeu L.şi colab., 2008, Impact of climate change on grapevine culture durability. 31 st World Congress of Vine and Wine, 15-20 June, Verona, Italia.

6. Seleaninov T. G., 1936, Metodica de cercetare a climatului subtropical, Izd. Agrohidromet, Leningrad

8. Teodorescu Șt. și colab., 1987, Oenoclimatul României, Editura Științifică și Enciclopedică, București;

9. Tonietto J. - 2000, Le climat mondial de la viticulture et la liste des cépages associés. Système de Classification climatique multicritères des régions à l'echelle viticole. 23p. 